\title{
The generation of student engagement as a cognition-affect- behaviour process in a Twitter learning experience
}

\author{
Raúl Pérez-López, Raquel Gurrea-Sarasa, Carolina Herrando ${ }^{a}$, María José Martín-De Hoyos, \\ Victoria Bordonaba-Juste, Ana Utrillas Acerete \\ University of Zaragoza, ${ }^{\text {a }}$ University of Twente
}

\begin{abstract}
Twitter is a microblog that allows users to interact about a topic in online discussion. This makes it an interesting interactive tool with possibilities to increase student engagement and learning performance through active collaboration in an informal learning environment. However, few articles take a quantitative approach to investigate the creation of student engagement using this social networking site. To address this gap, we propose a series of activities conducted through Twitter to analyse the engagement generation process in a sample of 110 students in the first year of a business and administration degree at a large Spanish university. The results show that the engagement process is created through active collaborative learning and enjoyment, and that engaged students are more satisfied with the activity and perceive greater learning performance. This leads us to recommend teachers to encourage active and collaborative activities to make students more engaged and satisfied, and improve their performance.
\end{abstract}

Implications for practice or policy:

- Course leaders can use social networking sites to enhance learning performance and student engagement in collaborative learning activities.

- Encouraging the engagement generation process in e-learning experiences positively affects students' satisfaction with these experiences and their learning performance.

- Group activities are useful to promote student engagement in Twitter-based learning experiences.

- Activities consisting of applying the concepts studied in class to practical environments, and activities where students browse for online information and take part in a debate, are more enjoyable.

Keywords: student engagement, Twitter, active collaborative learning, enjoyment, satisfaction, learning performance, quantitative.

\section{Introduction}

Social networking sites (SNS) are Web 2.0 technologies that allow users to share information, create content and collaborate online with others (Eid \& Al-Jabri, 2016; Evans, 2014). Examples of SNS are Facebook, Twitter, YouTube, Instagram, Linkedin, Tinder, and Snapchat. They have become part of our everyday life, not only for the purpose of socialisation, but also as a way of working, and even learning (Alt, 2017; Denker, Manning, Heuett, \& Summers, 2018; Haythornwaite, 2016).

In higher education, the use of Twitter avails educational benefits through interactive and collaborative learning (Tur, Marín, \& Carpenter, 2017). Thus, teachers have incorporated social networking sites into their class activities as a way to motivate students, foster their learning performance, and increase their engagement (Bond, Buntins, Bedenlier, Zawacki-Richter, \& Kerres, 2020; Bower, 2016; Busselli, Holdan \& Rota, 2019; Hui, Li, Qian, \& Kwok, 2019; Junco, Elavsky, \& Heiberger, 2013; Schwartz \& Caduri, 2016; Soffer \& Yaron, 2017; Staines \& Lauchs, 2013). However, few of these studies have considered how to create engagement in a learning project conducted through Twitter (Castellanos, Haya, \& Urquiza-Fuentes, 2017; Luo, Shah, \& Cromptom, 2019; Schwartz \& Caduri, 2016). This is surprising, since Twitter is a microblogging-based social network that allows users to express themselves by posting a maximum of 280 characters per tweet, as well as to share a picture, a video or a link to a website, or to retweet or comment on other users' tweets (Murthy, 2013). Twitter is a pedagogical tool that facilitates active participation and enables collaborative behaviour, permitting students to be connected with teachers, amplifying class materials, and bridging the gap between formal and informal learning environments by enhancing student 
engagement beyond the classroom (Barn, 2016; Holland, 2019; Jagušt, Botički, \& So, 2018; Pérez-San Agustín, Muñoz-Merino, Alario-Hoyos, Soldani, \& Delgado-Kloos, 2015).

Previous studies have considered engagement as a single variable, focusing only on its outcomes and disregarding its antecedents. Few have taken into account that engagement is part of a process made up of cognitive, affective, and behavioural dimensions (Bond \& Bedenlier, 2019; Bond et al., 2020; Fredricks, Blumenfeld, \& Paris, 2004; Henrie, Halverson, \& Graham, 2015; Kahu \& Nelson, 2018; Xie, Heddy, \& Greene, 2019). The articles on student engagement in the Twitter context are scarce and call for further research (Ertmer, Sadaf, \& Ertmer, 2011; Henrie et al., 2015; Pallas, Eidenfalk, \& Engel, 2019; Schindler, Burkholder, Morad, \& Marsh, 2017; Tang \& Hew, 2017).

As a consequence, this article has two main objectives: first, to explore whether a learning experience based on Twitter conducted in an informal environment can foster student engagement; and, second, to propose a process of engagement generation, identifying which characteristics of the activity can contribute to generating engagement and, subsequently, learning performance. The learning experience was conducted with 110 students aged between 18 and 22, enrolled in a business administration degree at a Spanish university. To the best of our knowledge, this article is one of the few that addresses the engagement generation process from a quantitative perspective.

\section{Theoretical framework}

Student engagement has been described as an active cognitive motivation to participate in a task, showing an affective reaction and interest in the learning process, and entailing a positive behavioural conduct (Fredricks et al., 2004). The concept of engagement in education has been widely studied, and considers that individuals' engagement is the result of a process composed of cognitive, affective, and behavioural dimensions (Fredricks et al., 2004). Although this article also recognises that individuals can be engaged while experiencing only one of the engagement dimensions, we understand that engagement as a process is a result of a process composed of cognitive, affective, and behavioural dimensions, which is in line with the main research stream (Bond et al., 2020). While some authors hypothesise engagement as a multidimensional construct (Fredricks et al., 2004; Jang, Kim, \& Reeve, 2016; Kahu, 2013), most studies in higher education analyse it as a single construct (e.g., Alt, 2017; Hui et al., 2019; Junco et al., 2013; Junco, Heiberger, \& Loken, 2011; Shroff, Ting, \& Lam, 2019; West, Moore, \& Barry, 2015). This lack of consensus shows the need for a robust theorising of the engagement concept with quantitative analyses (Bond \& Bedenlier, 2019; Henrie et al., 2015; Krause \& Coates, 2008; Zaka, Fox, \& Docherty, 2019). Nevertheless, two conceptualisations can be also identified: one is the feeling of being engaged as a result of a higher involvement within the activity (unidimensional construct, hereafter referred to as student engagement); and the other is the engagement process that consists of the dimensions of the cycle (multidimensional process, hereafter referred to as the engagement process). In student engagement research, the concept has been addressed indistinctly from both perspectives. On the one hand, student engagement, discussing its antecedents and consequences, and, on the other hand, the engagement process as a multifaceted construct (Montgomery, Hayward, Dunn, Carbonaro, \& Amrhein, 2015; Shroff et al., 2019). However, in student engagement research, the conceptualisation remains inconclusive. This study considers student engagement as a feeling part of the multidimensional engagement process.

The purpose of our study is to bridge this gap in the student engagement literature in higher education, giving a definition of the multi-dimensional structure of the concept and quantitatively testing this definition in order to gain a deeper understanding of how engagement is generated among students. We define student engagement as a process where students enjoy and collaborate in the learning process, which subsequently engages them in this learning process, enhancing their satisfaction and learning performance.

This study theorises that the cognitive dimension is linked to the experience and knowledge acquired during individuals' interaction in the activity (Fredricks et al., 2004; Henrie et al., 2015). Active collaborative learning activities using new technologies in class, contribute to achieve students' engagement (BlascoArcas, Buil, Hernández-Ortega, \& Sese, 2013). From a unidimensional perspective, inside of a process, technology-enabled active learning increases interactive student engagement (Shroff et al., 2019). We consider that collaborative learning using social media in higher education acts as the cognitive dimension of the student engagement process. 
The cognitive appraisal of the learning experience will trigger an affective reaction (Bagozzi, Gopinath, \& Nyer, 1999). Fredricks et al. (2004) state that students show different emotions during the learning experience, and these emotions increase their engagement with the activity being performed. As well as in offline environments, in digital platforms the affective dimension has been narrowly linked to emotions, using social networks as a channel for expression (Serrano-Puche, 2016). This affective dimension refers to how enjoyable and satisfactory the learning experience is for students. According to Calder, Malthouse, and Schaedel (2009), enjoyment is part of the affective dimension of the engagement process. Satisfaction with the learning experience refers to the students' affective assessment of the learning experience and to the fact that the student is content with the activities performed and the process (Westbrook \& Oliver, 1991). Furthermore, satisfaction has been seen as a variable that is part of the engagement generation process (Alioon \& Delialioğlu, 2019). Hence, we consider that the affective dimension consists of enjoyment, student engagement with the learning process, and satisfaction, since the emotions experienced in the affective dimension are positive.

Finally, the behavioural dimension is defined as the individual behavioural changes resulting from the influence of the previous dimensions (Brodie, Ilic, Juric, \& Hollebeck, 2013). It has been shown that students who enjoy the activities and are engaged are likely to have a better learning performance (BlascoArcas et al., 2013; Eid \& Al-Jabri, 2016). Thus, this paper proposes that, in the context of higher education, the behavioural dimension is linked to students' learning performance. Figure 1 depicts our conceptual model.

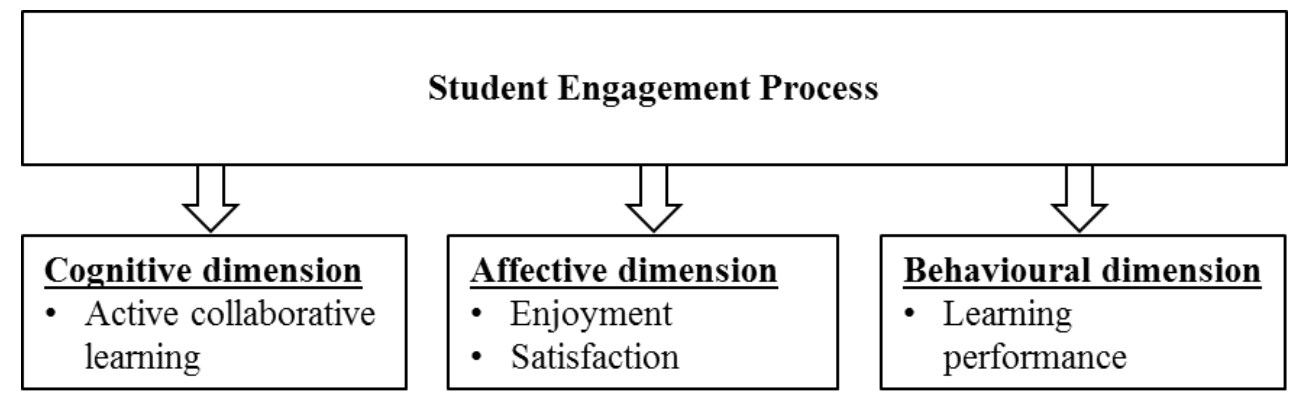

Figure 1. Conceptual model

\section{Literature review and development of hypotheses}

\section{The cognitive dimension of engagement process}

Active collaborative learning has received a great deal of attention in recent decades in educational technology literature (Gewerc, Montero, \& Lama, 2014; Walker et al., 2018). Collaborative learning is a philosophy of interaction in which individuals are responsible for their actions, including learning, and respect the abilities and contributions of their peers (Laal \& Gohdsi, 2012). From an educational perspective, teaching and learning in collaboration involves groups of learners working together to solve a problem or complete a task (Laal et al., 2012). In this context, learners have the opportunity to study the subject matter in greater depth (Kennedy \& Cuts, 2005), to promote their critical thinking skills, and to involve themselves actively in the learning process (Pantiz, 1999).

These positive effects of active collaborative learning on the student experience are enhanced when they are supported by the use of new technologies (Biassutti, 2017; Blasco-Arcas et al., 2013; Walker et al., 2018). Social media are widely considered to improve collaborative learning among students and researchers (Brown, 2012; Al-Rhami, Alias, Othman, Marin, Tur, 2018). According to Ratneswary and Rasiah (2014), social networking sites are effective tools to encourage collaborative learning. Facebook, for example, creates a more positive and less threatening learning environment which enhances the students' engagement and learning experience. Learning from peers through social media improves the engagement of students, enriches their learning activities, and facilitates group discussions, encouraging participation, since they are perceived as equals (Luo et al., 2019; Shroff et al., 2019). Collaborative learning is the cognitive dimension of the engagement generation process, so we propose:

H1: Active collaborative learning has a direct and positive effect on student engagement. 


\section{The affective dimension of engagement process}

Enjoyment is a positive emotion that can be experienced in both leisure and working activities. Increasing enjoyment will improve student learning processes because its effects are positively related to good outcomes (Baek \& Touati, 2017) and academic achievement (Torres-Díaz, Duart, Gómez-Alvarado, MarínGutiérrez, \& Segarra-Faggioni, 2016). The lack of enjoyment can cause school failure and disengagement (Shernoff, Csikzentmihalyi, Schneider, \& Shernoff, 2003). Csikszentmihalyi, Rahunde, and Whalen (1993) defined enjoyment as a positive feeling related to creative achievements, demonstration of skills, and learning performance. More recent works have found a positive effect of enjoyment on students' performance and effort (Schukajlow \& Krug, 2014).

Social networks, as a teacher communication tool, can be used to integrate students into the class and foster their learning experience (Gray, Vitak, Easton, \& Ellison, 2013). Likewise, social networks can serve to enhance students' engagement in learning environments (Hussein \& Hassan, 2017; Lederer, 2012). The stimulation of enjoyment in academic activities generates learning engagement (Case, 2007; Hamari et al., 2016). Therefore, enjoyment and student engagement seem to be interrelated concepts as they both contribute to improving the learning of students, which leads us to hypothesise that:

H2: Perceived enjoyment has a direct and positive effect on student engagement.

In e-learning experiences, students not only invest time and effort to increase their own knowledge, but also to feel enthusiasm, inspiration, pride, and challenge. That is, students must show greater engagement to achieve a high level of success (Banna, Lin, Stewart, \& Fialkowski, 2015; Britt, Goon, \& Timmerman, 2015; Meyer, 2014) and greater satisfaction with a course (Meyer, 2014; Shin \& Chan, 2004). In these contexts, the communication and interaction between students and their teachers can lead to students' satisfaction (Rubin, Fernandes, \& Avgerinou, 2013). As part of the affective dimension of the engagement process, satisfaction has been studied as one of the affective outcomes of student engagement (Bond \& Bedenlier, 2019; Filak \& Sheldon, 2018). Engaged students frequently experience positive emotions (Bindl \& Parker, 2010), developing a predisposition to show pro-active attitudes and enthusiastic perceptions about sharing a wider range of ideas in SNS which, in turn, can directly influence students' satisfaction. Therefore, we propose that:

H3: Student engagement has a direct and positive effect on satisfaction.

\section{The behavioural dimension of engagement process}

In higher education, students who are more motivated to learn will achieve higher levels of learning performance (Baker, Spiezio, \& Boland, 2004; Blasco-Arcas et al., 2013). Learning performance in our context refers to the improvement of students' knowledge and skills through their interaction with peers, the support of their teacher, and the study of the contents and materials of the courses. In the behavioural dimension of the engagement process, several studies have shown that learning performance is a behavioural outcome of student engagement (see Fredricks et al., 2004).

Traditional learning methods reflect a static form of learning, which do not allow students to interact with peers, teachers, and technologies. They are characterised by one-way communication and static roles: the teacher explains the lessons and the students listen, sitting in their chairs in silence and without interacting. However, technologies, and especially SNS, change this scenario and promote interactivity, which, in turn, is crucial to improve students' learning (Bannan-Ritland, 2002; Erickson \& Siau, 2003). SNS are learning tools that improve student engagement, offering more participation possibilities (Al-Rahmi et al., 2018; Junco et al., 2011; Meyer, 2014). The use of SNS per se is insufficient to generate an affective response over time (Shea et al., 2010). Teachers should encourage student engagement through active collaboration and enjoyable activities when using SNS. Thus, student engagement will improve learning performance (Al-Rahmi et al., 2018; Blasco-Arcas et al., 2013). As a consequence, we propose that:

H4: Student engagement has a direct and positive effect on learning performance. 
In the educational context, previous researchers have underlined that using SNS as learning tools improves students' academic results, but not only their learning performance and academic achievement but also their satisfaction (Al-Rahmi et al., 2018; Arquero, del Barrio-García, \& Romero-Frías, 2016; Cao \& Hong, 2011). When the students finish learning activities that employ SNS, they make a global assessment of their learning experience, analysing the feedback given by the teacher and their interaction with classmates. If the students' perceived value of the activity is higher than they expected, they will feel satisfied. Consequently, we propose that students who are satisfied using SNS, like Twitter, during the course activities will improve their skills and knowledge, leading them to achieve better outcomes.

H5: Students' satisfaction has a direct and positive effect on learning performance.

\section{Methods}

\section{Description of the learning experience and data collection}

The project consisted of three group activities that students carried out outside the classroom, with the aim to provide an informal online environment where students could put into practice the concepts that had already been taught in theory classes - which constitute the formal learning environments (Holland, 2019). The project was implemented in the subject Introduction to Marketing, taught in the first semester of the first course of the Bachelor of Business and Administration at a large Spanish university, which belongs to the European Higher Education Area.

Before beginning the first activity, the teachers of the subject created a Twitter account. The account was administered by two teachers. The teachers explained to the students how to use the social networking site and described what the activities would consist of and their programming during the course. The students were required to let their teachers know their usernames.

The objectives of the activities, which contained a video or image showing a concept or a phenomenon previously explained in the theory classes, were distributed through Moodle, the platform where students of this university can get all the materials in most of the subjects. The activities were conducted every 3 weeks, with the whole experience lasting 7 weeks, counting 1 week to conduct each activity. For each activity, students were asked either which concept or phenomenon they were considering, what objectives companies pursue with it, or how the companies can be affected by it. These questions were asked at the beginning of the activity. Students had to answer the questions on Twitter, and, after these first answers, the debate continued. The teachers could show their approval of these messages by liking and retweeting them. Furthermore, the students could like, retweet, and comment on their classmates' messages. The activity finished when the teacher provided the correct answers and proposed additional questions about ideas that had spontaneously appeared during the debate. All of the tweets had to include two hashtags so that students and teachers could track the activity. The first hashtag identified the activity and the other identified the group of students. This allowed teachers to monitor the activity and the participants. After finishing the three activities, the students filled in a questionnaire to uncover their perceptions of the project in terms of collaborative learning, enjoyment, student engagement, satisfaction, and learning performance. The questionnaire was completed by 170 students. Of these, 110 participated in all the activities and formed the valid sample of the present research.

\section{Variables measurement and common method variance}

The measurement of the variables was carried out using questions derived from previous research (Appendix A). The constructs were measured using a 7-point Likert scale, from 1 (completely disagree) to 7 (completely agree). All the variables were adapted from previous research, and measured through reflective constructs (Blasco-Arcas et al., 2013; Chang, Liang, Chou, \& Lin, 2017; Orús et al., 2016).

Common method variance can pose a problem for findings when both independent and dependent variables are collected through a questionnaire. This bias means that the variations in responses are caused by the instrument rather than the actual perceptions of the respondents. Statistically, if common method bias is present, a single factor should emerge from the exploratory factor analysis or a single factor would explain most of the covariance between variables (Krishnan, Martin, \& Noorderhaven, 2006; Podsakoff, MacKenzie, \& Podsakoff, 2003). Exploratory factor analysis revealed a solution formed by three latent 
variables that jointly explained $73.76 \%$ of the model variance, while the largest factor explained $33.16 \%$. As a result, there were no problems of common method bias found.

\section{Data analysis and results}

\section{Descriptive results}

Of the 110 students who participated in the activity, $91(83 \%)$ were aged between 18 and 19 years old, 1 was aged $17,10(9 \%)$ were 20 , and $8(7 \%)$ were 21 or 22 . Women made up $49 \%(54)$ of the participants. Regarding their participation in social networking sites, 107 (97.3\%) had participated at least once. They indicated their frequency of participation on a 7-point scale, and $88.5 \%$ scored between 5 and 7 . Twitter had been used at least once by $68(61.8 \%)$ and $39(58.2 \%)$ of them estimated a medium frequency of participation, between 3 and 5 . The main motivation to participate on Twitter was entertainment 98 (89.1\%), followed by satisfying information needs 68 (61.8\%). Other motivations were residual.

\section{Measurement model assessment}

The measurement analysis in structural equation modelling (SEM) is usually achieved by an exploratory factor analysis (EFA) and a confirmatory factor analysis (CFA). The EFA is useful to analyse the dimensionality of the constructs, that is, how many constructs exist in our set of observable variables. It should be completed by a subsequent CFA (Haig, 2010; Hair, Black, Babin, \& Anderson, 2010; Memon, Ting, Ramayah, Chuah, \& Cheah, 2017). The EFA, conducted with the software SPSS, revealed a solution formed by three reflective constructs: (1) student engagement, (2) learning performance and satisfaction, and (3) collaborative learning and enjoyment. The CFA, conducted with the software SmartPLS 3.0 (Ringle, Wende, \& Becker, 2015), revealed a solution of five constructs. In this case, learning performance and satisfaction loaded onto different constructs, as did collaborative learning and enjoyment. We must interpret these results considering reliability and convergent and discriminant validity of the constructs (Nunnally, 1978; Gefen, Straub, \& Boudreau, 2000).

Every item loaded higher on its respective construct and all loadings were higher than 0.7 , except for the item ENG2 of the construct of student engagement (Table 1). We decided to eliminate this item because its loading was 0.407, and this resulted in an improvement of Cronbach's alpha and the average variance extracted (AVE) for this construct. The values of Cronbach's alpha and composite reliability exceeded the minimum of 0.7 , confirming construct reliability (Nunnally, 1978). With respect to convergent validity, the values of the AVE were above 0.5 for all the latent variables (Ringle et al, 2015). Discriminant validity was addressed through Fornell and Larcker's (1981) criterion and the HTMT ratio (Henseler, Ringle, \& Sarstedt, 2015). The squared roots of AVE were higher than the correlations between pairs of constructs and the HTMT ratios were below the threshold of 0.875 for all the latent variables (Table 2). Thus, both criteria confirm discriminant validity. 
Table 1

Measurement model

\begin{tabular}{|c|c|c|c|c|c|}
\hline Construct & Items & $\begin{array}{c}\text { Loadings/weig } \\
\text { hts }\end{array}$ & $\begin{array}{c}\text { Cronbach's } \\
\text { alpha }\end{array}$ & $\begin{array}{c}\text { Composite } \\
\text { reliability }\end{array}$ & AVE \\
\hline \multirow{4}{*}{$\begin{array}{l}\text { Student } \\
\text { engagement }\end{array}$} & ENG1 & 0.873 & \multirow{4}{*}{0.847} & \multirow{4}{*}{0.907} & \multirow{4}{*}{0.764} \\
\hline & ENG2 & Eliminated & & & \\
\hline & ENG3 & 0.858 & & & \\
\hline & ENG4 & 0.891 & & & \\
\hline Learning & LP1 & 0.864 & \multirow{4}{*}{0.874} & \multirow{4}{*}{0.913} & \multirow{4}{*}{0.725} \\
\hline \multirow{3}{*}{ performance } & LP2 & 0.858 & & & \\
\hline & LP3 & 0.831 & & & \\
\hline & LP4 & 0.852 & & & \\
\hline \multirow{3}{*}{ Satisfaction } & SAT1 & 0.942 & \multirow{3}{*}{0.935} & \multirow{3}{*}{0.959} & \multirow{3}{*}{0.886} \\
\hline & SAT2 & 0.942 & & & \\
\hline & SAT3 & 0.939 & & & \\
\hline \multirow[t]{4}{*}{ Enjoyment } & EJ1 & 0.875 & \multirow{4}{*}{0.901} & \multirow{4}{*}{0.931} & \multirow{4}{*}{0.771} \\
\hline & EJ2 & 0.904 & & & \\
\hline & EJ3 & 0.858 & & & \\
\hline & EJ4 & 0.875 & & & \\
\hline Collaborative & CL1 & 0.904 & \multirow{4}{*}{0.940} & \multirow{4}{*}{0.957} & \multirow{4}{*}{0.847} \\
\hline \multirow[t]{3}{*}{ learning } & CL2 & 0.939 & & & \\
\hline & CL3 & 0.936 & & & \\
\hline & CL4 & 0.903 & & & \\
\hline
\end{tabular}

Table 2

Discriminant validity

\begin{tabular}{lccccc}
\hline & ENG & LP & SAT & EJ & CL \\
\hline ENG & 0.874 & 0.834 & 0.744 & 0.652 & 0.644 \\
\hline LP & 0.736 & 0.851 & 0.747 & 0.742 & 0.756 \\
\hline SAT & 0.673 & 0.683 & 0.941 & 0.753 & 0.731 \\
\hline EJ & 0.580 & 0.659 & 0.692 & 0.878 & 0.863 \\
\hline CL & 0.590 & 0.688 & 0.688 & 0.799 & 0.921
\end{tabular}

Note: Diagonal values are AVE squared roots. Below the diagonal: correlations between factors. Above the diagonal: the HT/MT ratio. ENG: student engagement; LP: learning performance; SAT: satisfaction; EJ: enjoyment; CL: collaborative learning.

\section{Structural model assessment}

The model was estimated applying SEM using the software SmartPLS 3.0 (Ringle et al., 2015). According to the results, the goodness-of-fit measures were adequate. To test predictive relevance, this software provides the $\mathrm{Q}^{2}$ proposed by Stone-Geisser. Our model showed positive $\mathrm{Q}^{2}$ values of the main endogenous variables, student engagement, learning performance, and satisfaction (Table 3). This indicated that our independent variables were relevant to explain the endogenous variables (Hair, Hult, Ringle, \& Sarstedt, 2017). The model had a high predictive capability given that the adjusted $R^{2}$ of the endogenous variables of the model was 0.373 for student engagement, 0.449 for satisfaction, and 0.594 for learning performance. Hypothesis testing indicates whether data supports the hypotheses or not, that is, whether the parameter that measures the relationship between two variables proposed in each hypothesis is significant or not. The common threshold levels of significance required in academic research are 0.05 or 0.01 (Cohen, 1988). H1, regarding the effect of collaborative learning (cognition) on student engagement, is supported. Regarding the affective component of the model, $\mathrm{H} 2$ is supported and enjoyment has a positive and significant effect on engagement. Furthermore, student engagement influences satisfaction, which supports H3. Finally, affect is a determinant of behaviour because both student engagement and satisfaction have positive effects on learning performance, supporting $\mathrm{H} 4$ and $\mathrm{H} 5$. 
Table 3

Results

\begin{tabular}{|c|c|c|c|c|c|}
\hline & & $\begin{array}{c}\text { Path } \\
\text { coefficient }\end{array}$ & $\mathrm{R}^{2}$ & $\mathrm{Q}^{2}$ & $\begin{array}{l}\text { Hypothesis } \\
\text { status }\end{array}$ \\
\hline \multirow[t]{2}{*}{ ENG } & $\mathrm{H}_{1}: \mathrm{CL} \rightarrow \mathrm{ENG}$ & $0.300^{* *}$ & \multirow{2}{*}{0.373} & \multirow{2}{*}{0.279} & Supported \\
\hline & $\mathrm{H}_{2}: \mathrm{EJ} \rightarrow \mathrm{ENG}$ & $0.350^{* * *}$ & & & Supported \\
\hline SAT & $\mathrm{H}_{3}: \mathrm{ENG} \rightarrow \mathrm{SAT}$ & $0.673^{* * *}$ & 0.449 & 0.394 & Supported \\
\hline \multirow[t]{2}{*}{ LP } & $\mathrm{H}_{4}: \mathrm{ENG} \rightarrow \mathrm{LP}$ & $0.341^{* * *}$ & \multirow{2}{*}{0.594} & \multirow{2}{*}{0.422} & Supported \\
\hline & $\mathrm{H}_{5}: \mathrm{SAT} \rightarrow \mathrm{LP}$ & $0.507^{* * *}$ & & & Supported \\
\hline \multirow[t]{3}{*}{ Control variables: } & Gender $\rightarrow$ LP & -0.003 & & & \\
\hline & Twitter Experience $\rightarrow$ LP & 0.009 & & & \\
\hline & Age $\rightarrow$ LP & -0.012 & & & \\
\hline
\end{tabular}

Note. ${ }^{* * *} p<0.01 ; * * p<0.05$. ENG: student engagement; LP: learning performance; SAT: satisfaction; EJ: enjoyment; CL: collaborative learning.

\section{Discussion and conclusions}

This paper aimed to explore whether a learning experience conducted through Twitter in an informal online learning environment could help in generating the engagement process through a cognitive-affectivebehavioural process (Brodie et al., 2013; Bond et al., 2020). Our results showed Twitter to be an adequate tool to create student engagement, which confirms the work of Junco et al. (2013). However, several differences exist. While the article of Junco et al. (2013) referred to the employment of Twitter in an online course, our approach was based on a learning experience made up of three activities undertaken outside of class in order to reinforce the acquisition of theoretical concepts. Junco et al. (2013) found that Twitter was a collaborative platform that favoured engagement process, whilst we found that the generation of the engagement process was a consequence, not only of the possibility of collaborating, but also of the enjoyment experienced during the learning process.

In addition, Tur et al. (2017) also analysed the use of Twitter in a required coursework. However, they did not examine the engagement generation process in this context and their experience was not led to combine formal and informal learning environments, as a way to reinforce the concepts that had been taught in theory lessons (formal environments) (Holland, 2019). The findings of this research confirmed the relationships proposed, so we can state that student engagement in learning activities based on Twitter, and undertaken outside of class, was a consequence of a cognitive-affective-behavioural process. First, the cognitive dimension of collaborative learning can encourage the generation of affect during the engagement process, to show a direct and positive relationship with the variable student engagement. This confirms previous research that had already found this effect of collaborative learning on student engagement and extends it by finding similar results in an e-learning activity based on Twitter considering this variable as a cognitive dimension (Al-Rhami et al., 2018; Blasco-Arcas et al., 2013).

Second, the affective stage of the engagement process is made up of enjoyment, student engagement, and satisfaction. This enjoyment is a positive feeling that is present in learning activities based on SNS and which encourages student engagement, confirming previous findings (DeAndrea, Ellison, LaRose, Steinfield, \& Fiore, 2012). Our study extends this finding to the study of engagement as a process in a learning activity based on Twitter. In addition, the engagement process positively affected the students' satisfaction with the activity, which confirms studies in contexts not related to SNS (Al-Rhami et al., 2018).

Finally, both satisfaction with the learning experience and student engagement as affective components of the engagement process positively influenced students' learning performance. This confirms that positive affective reactions can contribute to performance and goal achievement in learning tasks (Cao \& Hong, 2011; Hussein \& Hassan, 2017).

The contributions of this research are twofold. First, it explored engagement as a cognitive-affectivebehavioural process applying a quantitative method. We have demonstrated that students' perception of collaborative learning is a cognitive assessment that influences the affective dimension of the engagement process. Furthermore, enjoyment, student engagement itself, and satisfaction are part of the affective 
dimension, and student engagement and satisfaction directly improved learning performance. The second contribution was the analysis of the engagement generation process in a learning activity conducted through Twitter. We have shown that Twitter can be a useful tool to create an informal learning environment, generating engagement, and improving students' learning performance.

Our study offers several recommendations to teachers and educators who are willing to encourage student engagement in their classes with a learning activity based on Twitter. Firstly, Twitter is a valid SNS that can help teachers to conduct their e-learning activities out of class, since it creates an appropriate environment to encourage active collaborative learning and enjoyment. Thus, teachers can consider this SNS to create an informal learning environment that motivates students to continue practicing the concepts acquired in theoretical lessons. These informal environments can increase the students' feeling of freedom, encouraging their participation. Debate activities are a good opportunity to encourage students' reflection and participation. Secondly, the activities should be carried out in groups because, in this way, students will perceive greater collaborative learning and, consequently, will be more engaged. Therefore, teachers should propose interactive activities where students create, compare, and share knowledge. Thirdly, the activities should be enjoyable, containing phenomena or materials that are attractive to the students. For example, these activities should focus on how theoretical concepts are applied to practice in the real world. Activities where students realise the applicability of the concepts learned in class are usually more enjoyable and motivational. In-group activities are more enjoyable too due to social interaction between peers. Furthermore, Twitter allows students to easily browse for and post online information. Therefore, the activity should consist of searching for information online, to be posted in the forum. Finally, e-learning activities can increase students' learning performance by increasing their engagement with the activity.

This research suffers from some limitations. Firstly, the sample is limited to students from a single semester subject in a Spanish university degree. Further studies with students of other courses or degrees might provide different results. Secondly, we have focused on collaborative learning and enjoyment as generators of engagement because of the specific nature of Twitter. However, other SNS and other information technologies could use other generators, such as knowledge sharing or knowledge co-creation. Thirdly, despite the undeniable potential of technology to engage students (Bond \& Bedenlier, 2019), recent research has found that social media can also create negative experiences such as frustration, rejection, or disappointment turning into student disengagement (Bond et al., 2020). Hence, future lines of research would benefit from identifying negative indicators in the affective dimension that could lead to a reduction in engagement. Fourthly, we have conducted a quantitative study based on SEM and the data have been collected through a survey. The quantitative nature of the study increases its generalisation and trustworthiness thanks to the statistical procedure applied. However, a qualitative perspective could have added richness to the understanding of the e-learning experience, by incorporating the students and teachers' opinions on the development and benefits of this experience (Barn, 2016). One of the teachers' goals for future research is to conduct a focus group with students that allow us to assess their opinion about the advantages and disadvantages of the learning experience presented in this article. Furthermore, we plan to realise an observation that measures learning performance before and after the learning experience. 


\section{References}

Alioon, Y., \& Delialioğlu, Ö. (2019). The effect of authentic m-learning activities on student engagement and motivation. British Journal of Educational Technology, 50(2), 655-668 https://doi.org/10.1111/bjet.12559

Al-Rahmi, W. M., Alias, N., Othman, M. S., Marin, V. I., \& Tur, G. (2018). A model of factors affecting learning performance through the use of social media in Malaysian higher education. Computers \& Education, 121, 59-72. https://doi.org/10.1016/i.compedu.2018.02.010

Alt, D. (2017). Students' social media engagement and fear of missing out (FoMO) in a diverse classroom. Journal of Computing in Higher Education, 29(2), 388-410. https://doi.org/10.1007/s12528-017-9149-x

Arquero, J. L., del Barrio-García, S., \& Romero-Frías, E. (2016). What drives students' loyalty-formation in social media learning within a personal learning environment approach? The moderating role of need for cognition. Journal of Educational Computing Research, 55(4), 495-52. https://doi.org/10.1177/0735633116672056

Baek, Y., \& Touati, A. (2017). Exploring how individual traits influence enjoyment in a mobile learning game. Computers in Human Behaviour, 69, 347-357. https://doi.org/10.1016/j.chb.2016.12.053

Bagozzi, R. P., Gopinath, M., \& Nyer, P. U. (1999). The role of emotions in marketing. Journal of the Academy of Marketing Science, 27(2), 184-206. https://doi.org/10.1177/0092070399272005

Baker, K. Q., Spiezio, K. E., \& Boland, K. (2004). Student engagement: Transference of attitudes and skills to the workplace, profession, and community. The Industrial Organizational Psychologist, 42(2), 101-107. Retrieved from https://communityengagement.uncg.edu/wpcontent/uploads/2015/03/Baker.pdf

Banna, J., Lin, M. F. G., Stewart, M., \& Fialkowski, M. K. (2015). Interaction matters: Strategies to promote engaged learning in an online introductory nutrition course. Journal of Online Learning and Teaching, 11(2), 249-261. Retrieved from https://pubmed.ncbi.nlm.nih.gov/27441032/

Bannan-Ritland, B. (2002). Computer-mediated communication, e-learning, and interactivity: A review of the research. Quarterly Review of Distance Education, 3(2), 161-169. Retrieved from https://www.learntechlib.org/p/95271/

Barn, S. S. (2016). Tweet dreams are made of this, who are we to disagree? Adventures in a \#Brave New World of \#tweets, \#Twitter, \#student engagement and \#excitement with \#learning. Journal of Marketing Management, 32(9-10), 965-986. https://doi.org/10.1080/0267257X.2016.1159598

Biasutti, M. (2017). A comparative analysis of forums and wikis as tools for online collaborative learning. Computers \& Education, 111, 158-171. https://doi.org/10.1016/j.compedu.2017.04.006

Bindl, U. K., \& Parker, S. K. (2010). Feeling good and performing well? Psychological engagement and positive behaviours at work. In S. L. Albrecht (Ed.), Handbook of employee engagement: Perspectives, issues, research and practice (pp. 385-398). Cheltenham: Edward-Elgar Publishing.

Blasco-Arcas, L., Buil, I., Hernández-Ortega, B., \& Sese, F. J. (2013). Using clickers in class. The role of interactivity, active collaborative learning and engagement in learning performance. Computers \& Education, 62, 102-110. https://doi.org/10.1016/j.compedu.2012.10.019

Bond, M., \& Bedenlier, S. (2019). Facilitating student engagement through educational technology: Towards a conceptual framework. Journal of Interactive Media in Education, 2019(1), 1-14. http://doi.org/10.5334/jime.528

Bond, M., Buntins, K., Bedenlier, S., Zawacki-Richter, O., \& Kerres, M. (2020). Mapping research in student engagement and educational technology in higher education: A systematic evidence map. International Journal of Educational Technology in Higher Education, 17(2), 1-30. https://doi.org/10.1186/s41239-019-0176-8

Bower, M. (2016). Deriving a typology of web 2.0 learning technologies. British Journal of Educational Technology, 47(4), 763-777. https://doi.org/10.1111/bjet.12344

Britt, M., Goon, D., \& Timmerman, M. (2015). How to better engage online students with online strategies. College Student Journal, 49(3), 399-404.

Brodie, R.J., Ilic, A., Juric, B., \& Hollebeck, L. (2013). Consumer engagement in a virtual brand community: An explanatory analysis. Journal of Business Research, 65(1), 105-114. https://doi.org/10.1016/j.jbusres.2011.07.029

Brown, S. A. (2012). Seeing Web 2.0 in context: A study of academic perceptions. The Internet and Higher Education, 15(1), 50-57. https://doi.org/10.1016/j.iheduc.2011.04.003

Busselli, A. A., Holdan, E. G., \& Rota, D. R. (2019). Applying Twitter as an educational tool for concept learning and engaging students. In L. A. Tomei, \& D. D. Carbonara (Eds.) Handbook of research on 
diverse teaching strategies for the technology-rich classroom (pp. 125-137), Pittsburg, PA: IGI Global. https://doi.org/10.4018/978-1-7998-0238-9.ch010

Calder, B. J., Malthouse, E. C., \& Schaedel, U. (2009). An experimental study of the relationship between online engagement and advertising effectiveness. Journal of Interactive Marketing, 23(4), 321-331. https://doi.org/10.1016/j.intmar.2009.07.002

Cao, Y., \& Hong, P. (2011). Antecedents and consequences of social media utilization in college teaching: A proposed model with mixed-methods investigation. On the Horizon, 19(4), 297306. https://doi.org/10.1108/10748121111179420

Case, J. (2007). Alienation and engagement: Exploring students' experiences of studying engineering. Teaching in Higher Education, 12(1), 119-133. https://doi.org/10.1080/13562510601102354

Castellanos, J., Haya, P. A., \& Urquiza-Fuentes, J. (2017). A novel group engagement score for virtual learning environments. IEEE Transactions on Learning Technologies, 10(3), 306-317. https://doi.org/10.1109/TLT.2016.2582164

Chang, C-C., Liang, C., Chou, P-N., \& Lin, G-Y. (2017). Is game-based learning better in flow experience and various types of cognitive load than non-game-based learning? Perspectives from multimedia and media richness. Computers in Human Behaviour, 71, 218-227. https://doi.org/10.1016/j.chb.2017.01.031

Cohen, J. (1988). Statistical power analysis for the behavioral sciences (2nd ed.). Hillsdale, NJ: Lawrence Erlbaum Associates, Publishers.

Csikszentmihalyi, M., Rathunde, K., \& Whalen, S. (1993). Talented teenagers: The roots of success and failure. New York, NY: Cambridge University Press.

DeAndrea, D. C., Ellison, N. B., LaRose, R., Steinfield, C., \& Fiore, A. (2012). Serious social media: On the use of social media for improving students' adjustment to college. The Internet and Higher Education, 15(1), 15-23. https://doi.org/10.1016/j.iheduc.2011.05.009

Denker, K. J., Manning, J., Heuett, K., \& Summers, M. E. (2018). Twitter in the classroom: Modeling online communication attitudes and student motivations to connect. Computers in Human Behaviour, 79, 1-8. https://doi.org/10.1016/j.chb.2017.09.037

Eid, M. I. M., \& Al-Jabri, I. M. (2016). Social networking, knowledge sharing, and student learning: The case of university students. Computers \& Education, 99, 14-27. https://doi.org/10.1016/j.compedu.2016.04.007

Erickson, J., \& Siau, K. (2003). Education. Communications of the ACM, 46(9), 134-140. https://doi.org/10.1145/903893.903928

Ertmer, P. A., Sadaf, A., \&Ertmer, D. J. (2011). Student-content interactions in online courses: The role of question prompts in facilitating higher-level engagement with course content. Journal of Computing in Higher Education, 23(2-3), 157-186. https://doi.org/10.1007/s12528-011-9047-6

Evans, C. (2014). Twitter for teaching: can social media be used to enhance the process of learning? British Journal of Educational Technology, 45(5), 902-915. https://doi.org/10.1111/bjet.12099

Filak, V. F., \& Sheldon, K. M. (2008). Teacher support, student motivation, student need satisfaction, and college teacher course evaluations: Testing a sequential path model. Educational Psychology, 28(6), 711-724. https://doi.org/10.1080/01443410802337794

Fornell, C., \& Larcker, D. L. (1981). Evaluating structural equation models with unobservable variables and measurement error. Journal of Marketing Research, 18(1), 39-50. https://doi.org/10.1177/002224378101800104

Fredricks, J. A., Blumenfeld, P. C., \& Paris, A. H. (2004). School engagement: Potential of the concept, state of the evidence. Review of Educational Research, 74(1), 59-109. https://doi.org/10.3102/00346543074001059

Gefen, D., Straub, D., \& Boudreau, M. C. (2000). Structural equation modeling and regression: Guidelines for research practice. Communications of the Association for Information Systems, 4(1), 177. https://doi.org/10.17705/1CAIS.00407

Gewerc, A., Montero, L., \& Lama, M. (2014). Collaboration and social networking in higher education. [Colaboración y redes sociales en la enseñanza universitaria]. Comunicar, 42(21), 55-63. https://doi.org/10.3916/C42-2014-05

Gray, R., Vitak, J., Easton, E. W., \& Ellison, N. B. (2013). Examining social adjustment to college in the age of social media: Factors influencing successful transitions and persistence. Computers \& Education, 67, 193-207. https://doi.org/10.1016/j.compedu.2013.02.021

Haig, B. D. (2010). Abductive research method. In P. Peterson, E. Baker, \& B. McGaw (Eds.), International encyclopedia of education (3rd ed., pp. 77-82). Elsevier Science. 
Hair, J., Black, W., Babin, B., \& Anderson, R. (2010). Multivariate data analysis (7th ed.). Upper Saddle River, NJ: Prentice-Hall.

Hair, J. F., Hult, G. T. M., Ringle, C. M., \& Sarstedt, M. (2017). A primer on partial least squares structural equation modeling (PLS-SEM) (2nd ed.). Thousand Oaks, CA: Sage.

Hamari, J., Shernoff, D. J., Rowe, E., Coller, B., Asbell-Clarke, J., \& Edwards, T. (2016). Challenging games help students learn: An empirical study on engagement, flow and immersion in game-based learning. Computers in Human Behaviour, 54, 170-179. https://doi.org/10.1016/j.chb.2015.07.045

Haythornthwaite, C. (2016). E-learning and new learning cultures and case: Social media in higher education [Power Point slides]. The University of Hong Kong.

Henrie, C. R., Halverson, L. R., \& Graham, C. R. (2015). Measuring student engagement in technologymediated learning: A review. Computers \& Education, 90, 36-53. https://doi.org/10.1016/j.compedu.2015.09.005

Henseler, J., Ringle,C. M., \& Sarstedt, M. (2015). A new criterion for assessing discriminant validity in variance-based structural equation modeling. Journal of the Academy of Marketing Science, 43(1), 115-35. https://doi.org/10.1007/s11747-014-0403-8

Holland, A. A. (2019). Effective principles of informal online learning design: A theory-building metasynthesis of qualitative research. Computers \& Education, 128, 214-226. https://doi.org/10.1016/j.compedu.2018.09.026

Hui, Y. K., Li, C., \& Qian, S., \& Kwok, L. F. (2019). Learning engagement via promoting situational interest in a blended learning environment. Journal of Computing in Higher Education, 31(2), 408425. https://doi.org/10.1007/s12528-019-09216-Z

Hussein, R., \& Hassan, S. (2017). Customer engagement on social media: How to enhance continuation of use. Online Information Review, 41(7), 1006-1028. https://doi.org/10.1108/OIR-02-2016-0047

Jagušt, T., Botički, I., \& So, H-J. (2018). A review of research on bridging the gap between formal and informal learning with technology in primary school contexts. Journal of Computer Assisted Learning, 34(4), 417-428. https://doi.org/10.1111/jcal.12252

Jang, H., Kim, E. J., \& Reeve, J. (2016). Why students become more engaged or more disengaged during the semester: A self-determination theory dual-process model. Learning and Instruction, 43, 27-38. https://doi.org/10.1016/j.learninstruc.2016.01.002

Junco, R., Elavsky, C. M., \& Heiberger, G. (2013). Putting twitter to the test: Assessing outcomes for student collaboration, engagement and success. British Journal of Educational Technology, 44(2), 273-287. https://doi.org/10.1111/i.1467-8535.2012.01284.x

Junco, R., Heiberger, G., \& Loken, E. (2011). The effect of Twitter on college student engagement and grades. Journal of Computer Assisted Learning, 27(2), 119-132. https://doi.org/10.1111/j.13652729.2010.00387.x

Kahu, E. R. (2013). Framing student engagement in higher education. Studies in Higher Education, 38(5), 758-773. https://doi.org/10.1080/03075079.2011.598505

Kahu, E. R., \& Nelson, K. (2018). Student engagement in the educational interface: Understanding the mechanisms of student success. Higher Education Research \& Development, 37(1), 58-71. https://doi.org/10.1080/07294360.2017.1344197

Kennedy, G. E., \& Cutts, Q. I. (2005). The association between students' use of an electronic voting system and their learning outcomes. Journal of Computer Assisted Learning, 21(4), 260-268. https://doi.org/10.1111/j.1365-2729.2005.00133.x

Koufaris, M. (2002). Applying the technology acceptance model and flow theory to online consumer behaviour. Information Systems Research, 13(2), 205-223. https://doi.org/10.1287/isre.13.2.205.83

Krause, K. L., \& Coates, H. (2008). Student engagement in first-year university. Assessment \& Evaluation in Higher Education, 33(5), 493-505. https://doi.org/10.1080/02602930701698892

Krishnan, R., Martin, X., \& Noorderhaven, N.G. (2006). When does trust matter to alliance performance? Academy of Management Journal, 49(5), 894-917. https://doi.org/10.5465/amj.2006.22798171

Laal, M., \& Ghodsi, S. M. (2012). Benefits of collaborative learning. Procedia-Social and Behavioral Sciences, 31, 486-490. https://doi.org/10.1016/j.sbspro.2011.12.091

Lederer, K. (2012). Pros and cons of social media in the classroom. Campus Technology, 25(5), 1-2. Retrieved from https:/campustechnology.com/articles/2012/01/19/pros-and-cons-of-social-media-inthe-classroom.aspx

Luo, T., Shah, S. J., \& Cromptom, H. (2019). Using Twitter to support reflective learning in an asynchronous online course. Australasian Journal of Educational Technology, 35(3), 31-44. https://doi.org/10.14742/ajet.4124 
MacGeorge, E. L., Homan, S. R., Dunning, J. B., Elmore, D., Bodie, G. D., Evans, E., ... Lichti, S. M. (2008). The influence of learning characteristics on evaluation of audience response technology. Journal of Computing in Higher Education, 19(2), 25-46. https://doi.org/10.1007/BF03033425

Memon, M. A., Ting, H., Ramayah, T., Chuah, F., \& Cheah, J. H. (2017). A review of the methodological misconceptions and guidelines related to the application of structural equation modelling: A Malaysian scenario. Journal of Applied Structural Equation Modeling, 1(1), 1-13.

Meyer, K. A. (2014). Student engagement in online learning: What works and why. ASHE Higher Education Report, 40(6), 1-114. https://doi.org/10.1002/aehe.20018

Montgomery, A. P., Hayward, D. V., Dunn, W., Carbonaro, M., \& Amrhein, C. G. (2015). Blending for student engagement: Lessons learned for MOOCs and beyond. Australasian Journal of Educational Technology, 31(6), 658-670. https://doi.org/10.14742/ajet.1869

Murthy, D. (2013). Twitter: Social communication in the Twitter age. Cambridge: John Wiley \& Sons.

Nunnally, J. C. (1978). Psychometric theory. New York, NY: McGraw-Hill.

Orús, C., Barlés, M. J., Belanche, D., Casaló, L., Fraj, E., \& Gurrea, R. (2016). The effects of learnergenerated videos for YouTube on learning outcomes and satisfaction. Computers \& Education, 95, 254-269. https://doi.org/10.1016/j.compedu.2016.01.007

Pallas, J., Eidenfalk, J., \& Engel, S. (2019). Social networking sites and learning in international relations: The impact of platforms. Australasian Journal of Educational Technology, 35(1), 1627. https://doi.org/10.14742/ajet.3637

Panitz, T. (1999). The motivational benefits of cooperative learning. New Directions for Teaching and Learning, 78, 59-67. https://doi.org/10.1002/t1.7806

Pérez-San Agustín, M., Muñoz-Merino, P. J., Alario-Hoyos, C., Soldani, X., \& Delgado-Kloos, C. (2015). Lessons learned from the design of situated learning environments to support collaborative knowledge construction. Computers \& Education, 87, 70-82. https://doi.org/10.1016/j.compedu.2015.03.019

Podsakoff, P. M., MacKenzie, S. B., Lee, J. Y., \& Podsakoff, N. P. (2003). Common method biases in behavioral research: A critical review of the literature and recommended remedies. Journal of Applied Psychology, 88(5), 879-903. https://doi.org/10.1037/0021-9010.88.5.879

Ratneswary, V., \& Rasiah, R. (2014). Transformative higher education teaching and learning: Using social media in a team-based learning environment. Procedia-Social and Behavioral Sciences, 123, 369-379. https://doi.org/10.1016/j.sbspro.2014.01.1435

Ringle, C. M., Wende, S., \& Becker, J-M. (2015). SmartPLS 3. Retrieved from http://www.smartpls.com

Rubin, B., Fernandes, R., \& Avgerinou, M. D. (2013). The effects of technology on the community of inquiry and satisfaction with online courses. Internet and Higher Education, 17, 48-57. https://doi.org/10.1016/j.iheduc.2012.09.006

Schindler, L. A., Burkholder, G. J., Morad, O. A., \& Marsh, C. (2017). Computer-based technology and student engagement: A critical review of the literature. International Journal of Educational Technology in Higher Education, 14(1), 1-28. https://doi.org/10.1186/s41239-017-0063-0

Schukajlow, S., \& Krug, A. (2014). Are interest and enjoyment important for students' performance? Proceedings of the Joint Meeting of PME, 38, 129-136. Retrieved from https://ivv5hpp.unimuenster.de/u/sschu 12/pdf/Publikationen/Schukajlow_Krug_PME38-2014.pdf

Schwartz, B., \& Caduri, G. (2016). Novelties in the use of social networks by leading teachers in their classes. Computers \& Education, 102, 35-51. https://doi.org/10.1016/j.compedu.2016.07.002

Serrano-Puche, J. (2016). Internet and emotions: New trends in an emerging field of research. [Internet y emociones: Nuevas tendencias en un campo de investigación emergente]. Comunicar, 24(46), 19-26.

Shea, P., Hayes, S., Vickers, J., Gozza-Cohen, M., Uzuner, S., Mehta, R., \& Rangan, P. (2010). A reexamination of the community of inquiry framework: Social network and content analysis. Internet and Higher Education, 13(1-2), 10-21. https://doi.org/10.1016/j.iheduc.2009.11.002

Shernoff, D. J., Csikszentmihalyi, M., Schneider, B., \& Shernoff, E. S. (2003). Student engagement in high school classrooms from the perspective of flow theory. School Psychology Quarterly, 18(2), 158176. https://doi.org/10.1521/scpq.18.2.158.21860

Shin, N., \& Chan, J. K. Y. (2004). Direct and indirect effects of online learning on distance education. British Journal of Educational Technology, 35(3), 275-288. https://doi.org/10.1111/j.00071013.2004.00389.x

Shroff, R. H., Ting, F. S. T., \& Lam, W. H. (2019). Development and validation of an instrument to measure students' perceptions of technology-enabled active learning. Australasian Journal of Educational Technology, 35(4), 109-127. https://doi.org/10.14742/ajet.4472 
So, H. J., \& Brush, T. A. (2008). Student perceptions of collaborative learning, social presence and satisfaction in a blended learning environment: Relationships and critical factors. Computers \& Education, 51(1), 318-336. https://doi.org/10.1016/j.compedu.2007.05.009

Soffer, T., \& Yaron, E. (2017). Perceived learning and students' perceptions toward using tablets for learning: the mediating role of perceived engagement among high school students. Journal of Educational Computing Research, 55(7), 951-973. https://doi.org/10.1177/0735633117689892

Staines, Z., \& Lauchs, M. (2013). Student engagement with Facebook in a university undergraduate policing unit. Australasian Journal of Educational Technology, 29(6), 792-805. https://doi.org/10.14742/ajet.270

Tang, Y., \& Hew, K. F. (2017). Using Twitter for education: Beneficial or simply a waste of time? Computers \& Education, 106, 97-118. https://doi.org/10.1016/j.compedu.2016.12.004

Torres-Díaz, J. C., Duart, J. M., Gómez-Alvarado, H. F., Marín-Gutiérrez, I., \& Segarra-Faggioni, V. (2016). Internet use and academic success in university students. Comunicar, 24(48), 61-69. https://doi.org/10.3916/C59-2019-07

Tur, G., Marín, V. I., \& Carpenter, J. (2017). Using Twitter in higher education in Spain and the USA. Comunicar, 25(51), 19-28. https://doi.org/10.3916/C51-2017-02

Walker, R. J., Spangler, B. R., Lloyd, E. P., Walker, B. L., Wessels, P. M., \& Summerville, A. (2018). Comparing active learning techniques: The effect of clickers and discussion groups on student perceptions and performance. Australasian Journal of Educational Technology, 34(3), 74-87. https://doi.org/10.14742/ajet.3337

West, B., Moore, H., \& Barry, B. (2015). Beyond the tweet: Using Twitter to enhance engagement, learning, and success among first-year students. Journal of Marketing Education, 37(3), 160-170. https://doi.org/10.1177/0273475315586061

Westbrook, R. A., \& Oliver, R. L. (1991). The dimensionality of consumption emotion patterns and consumer satisfaction. Journal of Consumer Research, 18(1), 84-91. https://doi.org/10.1086/209243

Xie, K., Heddy, B. C., \& Greene, B. A. (2019). Affordances of using mobile technology to support experience-sampling method in examining college students' engagement. Computers \& Education, 128, 183-198. https://doi.org/10.1016/j.compedu.2018.09.020

Zaka, P. A., Fox, W. H., \& Docherty, P. D. (2019). Student perspectives of independent and collaborative learning in a flipped foundational engineering course, Australasian Journal of Educational Technology, 35(5), 79-94. https://doi.org/10.14742/ajet.3804

Corresponding author: Carolina Herrando, c.herrando@utwente.nl

Copyright: Articles published in the Australasian Journal of Educational Technology (AJET) are available under Creative Commons Attribution Non-Commercial No Derivatives Licence (CC BY-NCND 4.0). Authors retain copyright in their work and grant AJET right of first publication under CC BYNC-ND 4.0.

Please cite as: Pérez-López, R., Gurrea-Sarasa, R., Herrando, C., Martín-De Hoyos, M. J., BordonabaJuste, V., \& Utrillas-Acerete, A. (2020). The generation of student engagement as a cognition-affectbehaviour process in a Twitter learning experience. Australasian Journal of Educational Technology, 36(3), 132-146. https://doi.org/10.14742/ajet.5751 


\section{Appendix A}

\section{Scales}

\begin{tabular}{|c|c|c|}
\hline Variable & Scale & Source \\
\hline $\begin{array}{l}\text { Collaborative } \\
\text { learning }\end{array}$ & $\begin{array}{l}\text { CL1. I felt that I actively collaborated in my learning experience. } \\
\text { CL2. I felt that I have co-created my own learning experience. } \\
\text { CL3. I felt that I had free reign to co-create my own learning } \\
\text { experience. } \\
\text { CL4. I felt that I had freedom to participate in my own learning } \\
\text { experience. }\end{array}$ & $\begin{array}{l}\text { Blasco-Arcas } \\
\text { et al., 2013; } \\
\text { So \& Brush, } \\
2008\end{array}$ \\
\hline Enjoyment & $\begin{array}{l}\text { EJ1. I found the activity interesting. } \\
\text { EJ2. The activity was enjoyable. } \\
\text { EJ3. I found the activity exciting. } \\
\text { EJ4. The activity was fun. }\end{array}$ & $\begin{array}{l}\text { Koufaris, } \\
2002\end{array}$ \\
\hline $\begin{array}{l}\text { Student } \\
\text { engagement }\end{array}$ & $\begin{array}{l}\text { ENG1. I became deeply involved in the learning material. } \\
\text { ENG2. During the course I was distracted. } \\
\text { ENG3. I work hard to be engaged in the learning material. } \\
\text { ENG4. I was concentrated during the course. }\end{array}$ & $\begin{array}{l}\text { Chang et al., } \\
2017\end{array}$ \\
\hline $\begin{array}{l}\text { Learning } \\
\text { performance }\end{array}$ & $\begin{array}{l}\text { The activity ... } \\
\text { LP1. Has improved my comprehension of the concepts studied in } \\
\text { class. } \\
\text { LP2. Has led to a better learning experience in this module. } \\
\text { LP3. Has allowed me to increase my level of critical thinking. } \\
\text { LP4. I will retain more material as a result of using the wiki. }\end{array}$ & $\begin{array}{l}\text { Blasco-Arcas } \\
\text { et al. 2013; } \\
\text { MacGeorge } \\
\text { et al., } 2008\end{array}$ \\
\hline Satisfaction & $\begin{array}{l}\text { SAT1. I am satisfied with the teaching method applied in this } \\
\text { course. } \\
\text { SAT2. I am satisfied with the knowledge I have acquired in this } \\
\text { course. } \\
\text { SAT3. The experience I have had in this course has been } \\
\text { satisfactory. }\end{array}$ & $\begin{array}{l}\text { Orús et al., } \\
2016\end{array}$ \\
\hline
\end{tabular}

